\title{
Evaluation of Antioxidant Activities, Oxidation Enzymes, and Quality of Nano-Coated Button Mushrooms (Agaricus Bisporus) during Storage
}

\author{
Rokayya Sami ${ }^{1, *}$, Abeer Elhakem ${ }^{2}$, Mona Alharbi ${ }^{2}$, Nada Benajiba ${ }^{3}$, Manal Almatrafi ${ }^{1}$, Amro Abdelazez $^{4,5}$ (D) \\ and Mahmoud Helal ${ }^{6}$
}

1 Department of Food Science and Nutrition, College of Sciences, Taif University, P.O. Box 11099, Taif 21944, Saudi Arabia; manal.almatrafi@uconn.edu

2 Department of Biology, College of Science and Humanities in Al-Kharj, Prince Sattam Bin Abdulaziz University, Al-Kharj 11942, Saudi Arabia; a.elhakem@psau.edu.sa (A.E.); mh.alharbi@psau.edu.sa (M.A.)

3 Department of Basic Health Sciences, Deanship of Preparatory Year, Princess Nourah Bint Abdulrahman University, P.O. Box 84428, Riyadh 11671, Saudi Arabia; nabenajiba@pnu.edu.sa

4 College of Agriculture and Forestry, Linyi University, Linyi 276005, China; amorbiotic@yahoo.com

5 Agriculture Research Centre, Department of Dairy Microbiology, Animal Production Research Institute, Dokki, Giza 12618, Egypt

6 Department of Mechanical Engineering, Faculty of Engineering, Taif University, P.O. Box 11099, Taif 21944, Saudi Arabia; mo.helal@tu.edu.sa

* Correspondence: rokayya.d@tu.edu.sa

check for updates

Citation: Sami, R.; Elhakem, A.; Alharbi, M.; Benajiba, N.; Almatrafi, M.; Abdelazez, A.; Helal, M. Evaluation of Antioxidant Activities, Oxidation Enzymes, and Quality of Nano-Coated Button Mushrooms (Agaricus Bisporus) during Storage. Coatings 2021, 11, 149. https:// doi.org/10.3390/coatings11020149

Received: 4 January 2021

Accepted: 20 January 2021

Published: 29 January 202

Publisher's Note: MDPI stays neutral with regard to jurisdictional claims in published maps and institutional affiliations.

Copyright: (C) 2021 by the authors Licensee MDPI, Basel, Switzerland. This article is an open access article distributed under the terms and conditions of the Creative Commons Attribution (CC BY) license (https:// creativecommons.org/licenses/by/ $4.0 /)$.

\begin{abstract}
Agaricus Bisporus is an edible button mushroom that is highly perishable with an extremely short shelf-life at ambient temperature. This work aims to evaluate some antioxidant activities, oxidation enzymes, and determine postharvest qualities of nano-coated mushrooms with the combination of chitosan (CHN) component during storage at $4{ }^{\circ} \mathrm{C}$ for $(0,3,6,9$, and 12 days). Silica/CHN Film strongly delayed the mushroom respiratory spike onset and blocked carbon dioxide passage from inside to the outside, while Titanium/CHN Film $\left(0.035 \mathrm{mmol} \mathrm{s}^{-1} \mathrm{~kg}^{-1}\right)$ established the lowest $\mathrm{O}_{2}$ production rate and thiobarbituric acid reactive substances production $\left(6.21 \mathrm{nmol} \mathrm{g}^{-1}\right)$. Silica/CHN Film was mainly effectual for the polyphenol contents $\left(0.39 \mathrm{~g} \mathrm{~kg}^{-1}\right)$ and antioxidant activities (78.14\% and 71.09\%) for DPPH and ABTS+ radical scavenging activities, respectively. The results reported that Silica/CHN Film induced the highest (catalase and ascorbate peroxidase) activities, while Titanium/CHN Film recorded the highest (peroxidase and superoxide dismutase) activities of antioxidant enzymes. Besides, Titanium/CHN Film preserved relatively lower contents of hydrogen peroxide $\left(22.40 \mu \mathrm{mol} \mathrm{g}^{-1}\right)$ and hydroxyl radical $\left(0.16 \mu \mathrm{mol} \mathrm{g}^{-1}\right)$. In a word, nano-materials used in coating films such as titanium or even silica with the combination of $\mathrm{CHN}$ can directly reduce the cell degradation, oxidation processes and enhance the harvested horticultural crops.
\end{abstract}

Keywords: Agaricus Bisporus; nano-coating; storage; oxidation enzymes; antioxidant activities; quality

\section{Introduction}

Button mushroom (Agaricus Bisporus) is one of the most important edible mushrooms, the genus includes about $40 \%$ of the total world mushroom production due to its free radical scavenging activities. Mushrooms contain high protein content, digestible carbohydrates, low fats, vitamins such as B, D, K, A, and C [1]. Mushroom is well-known as therapeutic foods for preventing several diseases such as cancer, hypertension, and hypercholesterolemia in addition to having antitumor, anti-inflammatory, antimicrobial, antioxidant, and immunomodulatory properties [2]. Though, the high perishable nature of mushrooms remains a problem; as mushroom can lose their quality quickly within few 
days due to occurrences such as physiological injuries, enzymatic browning, off-flavor, loss of firmness of the cap opening, fungal growth owing to senescence, water loss during the storage at commercial temperature due to oxidative reactions. In a comparison with other fruits and vegetables, the mushroom's respiration rate is higher due to its thin structure (200 to $500 \mathrm{mg} / \mathrm{kg} \mathrm{h}$ at $20^{\circ} \mathrm{C}$ ) [3]. As a result, mushrooms need special preservation treatments such as washing with various solutions as sodium hypochlorite, citric acid or even overwrapped with polyvinyl chloride films [4]. Atmosphere modification with a higher amount of carbon dioxide and poorer in oxygen can be able to adjust the metabolism, respiration rate, and other physiological activities [5]. Potentially alternative methods were applied to extend the shelf-life, reduce moisture loss, microbial contamination, improve color and appearance such as refrigeration, cultivating with calcium dichloride, ionizing radiation, and coating [6-8]. Chitosan, as an edible biopolymer, is commonly used for coating due to its antibacterial activities, and low toxicity [9]. Nanotechnology application coating films have been proposed as fillers to prolong the shelf life of several products by international agencies including (FAO/WHO/AFDA) Food and Agriculture Organization, World Health Organization, and Association of Federal Defense Attorneys who concluded that nano-materials with low concentrations can be considered safe in the cosmetics and food industry [10,11]. Nano-films such as titanium and silica dioxides are used to control exposition to light and oxygen, reduce dehydration, respiration, transpiration, enzyme oxidation, and microbial attack. Besides, achieving the customer acceptability and extending shelf-life [12].

Hence, the present study was conducted to evaluate the oxidation enzymes, antioxidant activities, and quality of nano-coated button mushrooms during storage at refrigeration conditions.

\section{Materials and Methods}

\subsection{Materials and Films Preparation}

Chitosan (degree of deacetylation: 85\%), Titanium, Silica dioxides nanoparticles $(15 \mathrm{~nm})$ were from (Sigma Aldrich, Saint Louis, MO, USA). Materials and reagents were used to prepare chitosan $(\mathrm{CHN})$ film with the addition of acetic acid (1\%), and glycerol (0.5\%). Silica/CHN and Titanium/CHN films were prepared by blending CHN (1\%) with nanoparticles (1\%) in distilled water for $12 \mathrm{~h}$ and sonication $400 \mathrm{~W}$ at $70{ }^{\circ} \mathrm{C}$ (KQ-250 E, Kunshan ultrasonic instrument Co., Ltd., Kunshan, China). The film preparation and coating techniques are presented in Figure 1. The dipping technique was used for coating with $450 \mathrm{~mL}$ of deposited solution.

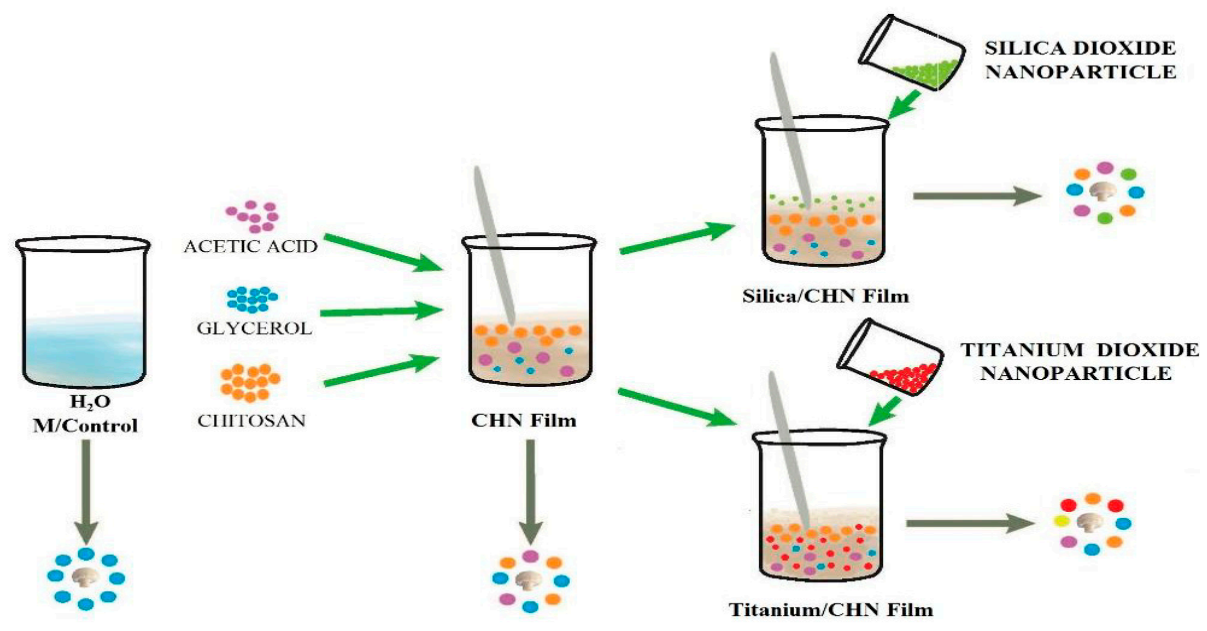

Figure 1. Films preparation. 


\subsection{Scanning Electron Microscopy (SEM) Analysis}

The microstructures of the prepared films were characterized by using a Hitachi 8020 Scanning electron microscopy (SEM, Tokyo, Japan). The flat plate films with a thickness of $1 \mathrm{~mm}$ were fractured in nitrogen liquid at $5 \mathrm{kV}$. All films were fixed on an aluminum stub with an adhesive and sputtered with platinum in an airtight chamber.

\subsection{Mushrooms, Treatments, and Storage}

A uniform size, color, appearance, and ripeness button mushrooms with $(75 \%-80 \%)$ relative humidity were supplied from the food science laboratory at Taif University. Mushrooms were divided into four groups; the control group was washed well with distilled water and then air-dried. CHN, silica/CHN, and titanium/CHN films were applied on mushroom samples by washing for $15 \mathrm{~min}$ then dried by industrial fan until dry. Mushroom samples were packaged in a zipped lock polyethylene bags [13]. All experiments were chilled at $4{ }^{\circ} \mathrm{C}$ and carried out at $0,3,6,9$, and 12 days of storage.

\subsection{Measurement of $\mathrm{CO}_{2}$ Respiration Rate}

Mushroom samples were exposed to the ambient condition for one hour to allow carbon dioxide to diffuse into the surrounding air. After that, mushrooms were kept in an air-tight jar with the addition of $10 \mathrm{~mL}$ of $0.4 \mathrm{~mol} / \mathrm{L}^{-1}$ sodium hydroxide followed by 2 drops of phenolphthalein and titration with $0.2 \mathrm{~mol} / \mathrm{L}^{-1}$ oxalic acid [14].

\subsection{Measurement of $\mathrm{O}_{2}$ Production Rate}

Approximately $2 \mathrm{~g}$ of button mushroom samples were blended with $5 \mathrm{~mL}$ of $50 \mathrm{mmol} / \mathrm{L}$ and adjusted to (pH 7.8) Phosphate Buffered Saline (PBS) was then centrifuged at speed of $10,000 \mathrm{r} / \mathrm{min}$ for $20 \mathrm{~min}$ at $4{ }^{\circ} \mathrm{C}$, and filtrated for the supernatant. Aliquant of $(0.5 \mathrm{~mL})$ supernatant was adjusted by $0.5 \mathrm{~mL}$ of $50 \mathrm{mmol} / \mathrm{L}(\mathrm{pH} 7.8) \mathrm{PBS}$ and $1 \mathrm{~mL}$ of $1 \mathrm{mmol} / \mathrm{L}$ of $\mathrm{HONH}_{2} \cdot \mathrm{HCl}$, while distilled water was performed as a blank. The mixture was incubated for $20 \mathrm{~min}$ at ambient temperature. $1 \mathrm{~mL}$ of $7 \mathrm{mmol} / \mathrm{L} \mathrm{C}_{10} \mathrm{H}_{9} \mathrm{~N}$ and $1 \mathrm{~mL}$ of $50 \mathrm{mmol} / \mathrm{L}$ 4-((4-Aminophenyl) diazenyl) benzenesulfonic acid were added, and kept in a water bath at $25^{\circ} \mathrm{C}$ for $20 \mathrm{~min}$. The blend was incubated for $20 \mathrm{~min}$ at room temperature and evaluated at $530 \mathrm{~nm}$ [15].

\subsection{Bioactive Component and Antioxidant Activities}

\subsubsection{Total Polyphenols}

The total polyphenol contents were evaluated in $10 \mathrm{~mL}$ of $80 \%$ methanol $(\mathrm{MeOH})$ with the help of Folin-Ciocalteu reagent [16]. An aliquant of $(2 \mathrm{~g})$ button mushrooms was extracted for $24 \mathrm{~h}$ at $4{ }^{\circ} \mathrm{C}$, centrifuged at $10,000 \mathrm{r} / \mathrm{min}$ for $15 \mathrm{~min}$ at $4{ }^{\circ} \mathrm{C}$. Approximately $0.7 \mathrm{~mL}$ of the supernatant was mixed with $0.3 \mathrm{~mL}$ of water, $5 \mathrm{~mL}$ reagent, and $4 \mathrm{~mL}$ of sodium carbonate, incubated in the dark for $2 \mathrm{~h}$ and evaluated at $765 \mathrm{~nm}$. The results were presented in $\mathrm{g} \mathrm{kg}^{-1}$ as gallic acid equivalents.

\subsubsection{Free Radical Scavenging Activity (DPPH) Assay}

1,1-diphenyl-2-picrylhydrazyl (DPPH) scavenging activity assay was applied with each mushroom sample by dissolving cap tissues $(2 \mathrm{~g})$ in $10 \mathrm{~mL} \mathrm{MeOH}$ and centrifuged at $6000 \mathrm{r} / \mathrm{min}$ for $15 \mathrm{~min}$ at $4{ }^{\circ} \mathrm{C}$ [17]. Then $50 \mu \mathrm{L}$ of mushroom extracts were added to $1.5 \mathrm{~mL}$ of Tris buffer, $1 \mathrm{~mL}$ of DPPH, and measured at $517 \mathrm{~nm}$, while $\mathrm{MeOH}$ was performed as a blank.

\subsection{3. $\mathrm{ABTS}^{+}$Radical Scavenging Assay}

2,20-azinobis-(3-ethylbenzothiazoline-6-sulfonic acid) $\left(\mathrm{ABTS}^{+}\right)$radical scavenging assay was applied with each mushroom being exposed to methanolic extracts and $(7 \mathrm{mM})$ $\mathrm{ABTS}^{+}, \mathrm{PBS} \mathrm{pH} 7.4$, and $(0.45 \mathrm{mM})$ potassium persulphate $[18,19]$. The absorbance was evaluated at $(734 \mathrm{~nm})$ and calculated as a percentage after incubation for $6 \mathrm{~min}$ at $30^{\circ} \mathrm{C}$, against PBS as a reference. 


\subsection{Oxidation Enzymes Determinations}

Peroxidase (POD), Superoxide dismutase (SOD), Catalase (CAT), and Ascorbate peroxidase (APX) activities were evaluated by using kits purchased from Solarbio (Beijing, China). Steps were applied according to the manufacturer's instructions.

\subsection{Reactive Oxygen Species (ROS) Production}

2.8.1. Hydrogen Peroxide $\left(\mathrm{H}_{2} \mathrm{O}_{2}\right)$ Determination

Mushrooms ( $300 \mathrm{mg}$ ) were blended with $4 \mathrm{~mL}$ of $0.1 \%$ trichloroacetic acid in an ice bath and centrifuged at $12,000 \mathrm{r} / \mathrm{min}$ for $20 \mathrm{~min}$ at $4{ }^{\circ} \mathrm{C}$ [20]. The supernatant $(0.5 \mathrm{~mL})$ was diluted in the dark with $0.5 \mathrm{~mL}$ of $10 \mathrm{mmol} / \mathrm{L}$ potassium phosphate buffers ( $\mathrm{pH} 7.0)$ and $1 \mathrm{~mL}$ of $10 \mathrm{M}$ potassium iodide, incubated for $1 \mathrm{~h}$, evaluated at $390 \mathrm{~nm}$, and expressed as $\mu \mathrm{mol} \mathrm{g}{ }^{-1}$.

\subsubsection{Hydroxyl Radical $(-\mathrm{OH})$ Determination}

Hydroxyl radicals $(-\mathrm{OH})$ assay is generated for mushroom samples by the Fenton's reaction. Mushrooms (50 mg) were mixed with $1 \mathrm{~mL}$ of $10 \mathrm{mmol} / \mathrm{L} \mathrm{Na}_{2} \mathrm{HPO}_{4} 2 \mathrm{H}_{2} \mathrm{O}(\mathrm{pH}$ 7.4) with $15 \mathrm{mmol} / \mathrm{L} 2$-deoxy-d-ribose at ambient temperature [8]. Approximately $0.7 \mathrm{~mL}$ of the mixture was added to $1 \mathrm{~mL}$ of glacial acetic acid and $3 \mathrm{~mL}$ of $0.5 \%$ thiobarbituric acid. The absorbance was evaluated at $532 \mathrm{~nm}$, and calculated as $\mu \mathrm{mol} \mathrm{g}{ }^{-1}$.

\subsection{Thiobarbituric Acid-Reactive Substances (TBARS) Determination}

Approximately ( $2 \mathrm{~g}$ ) of mushroom samples were mixed with $15 \mathrm{~mL}$ of $50 \mathrm{mmol} / \mathrm{L}$ Tris Hydrochloride buffer and centrifuged at a high speed for $15 \mathrm{~min}$ at $4{ }^{\circ} \mathrm{C}$. Approximately $(0.2 \mathrm{~mL})$ of $200 \mathrm{~g} / \mathrm{L}$ Tricyclic antidepressant, $0.8 \%$ thiobarbituric acid (TBA, $150 \mu \mathrm{L}$ ) were added to $4 \mathrm{~mL}$ of the supernatant and maintained in a water bath at $95^{\circ} \mathrm{C}$ for $1 \mathrm{~h}$, cooled rapidly, centrifuged at $8000 \mathrm{r} / \mathrm{min}$ for $20 \mathrm{~min}$ and evaluated at 450, 532 and $600 \mathrm{~nm}$. The data were calculated as nmol g ${ }^{-1}[21]$.

\subsection{Statistical Analysis}

The mushroom treatments involved were stored for $(0,3,6,9$, and 12) days. The experiments were conducted in triplicates and data were analyzed by using variance (ANOVA) test and exported to SPSS ${ }^{\circledR}$ (Version 22.00) for analysis.

\section{Results and Discussion}

\subsection{SEM Analysis}

SEM analysis reflects the micro-structure, distribution uniformity, components, dispersion state to prove the film barrier performance [22]. The SEM images of CHN films with titanium, silica dioxides nanoparticles were presented in Figure 2. CHN film surface was noticed to be smooth and spotless appearance, furthermore, the cross-section form was organized and exhibited a number of order fiber as structure (Figure 2a,b). It can be noticed that a number of unobvious aggregates and scattered particles of silica dioxide nanoparticles were observed at the film surface, presenting the successful introduction of nano-silica, while the cross-section presented slight changes with a rough profile (Figure 2c,d). For the titanium dioxide nanoparticle film, the surface shown was rough and has few large bulks, while the cross-section form exhibited a few consolidated lamellar microstructures (Figure 2e,f). 

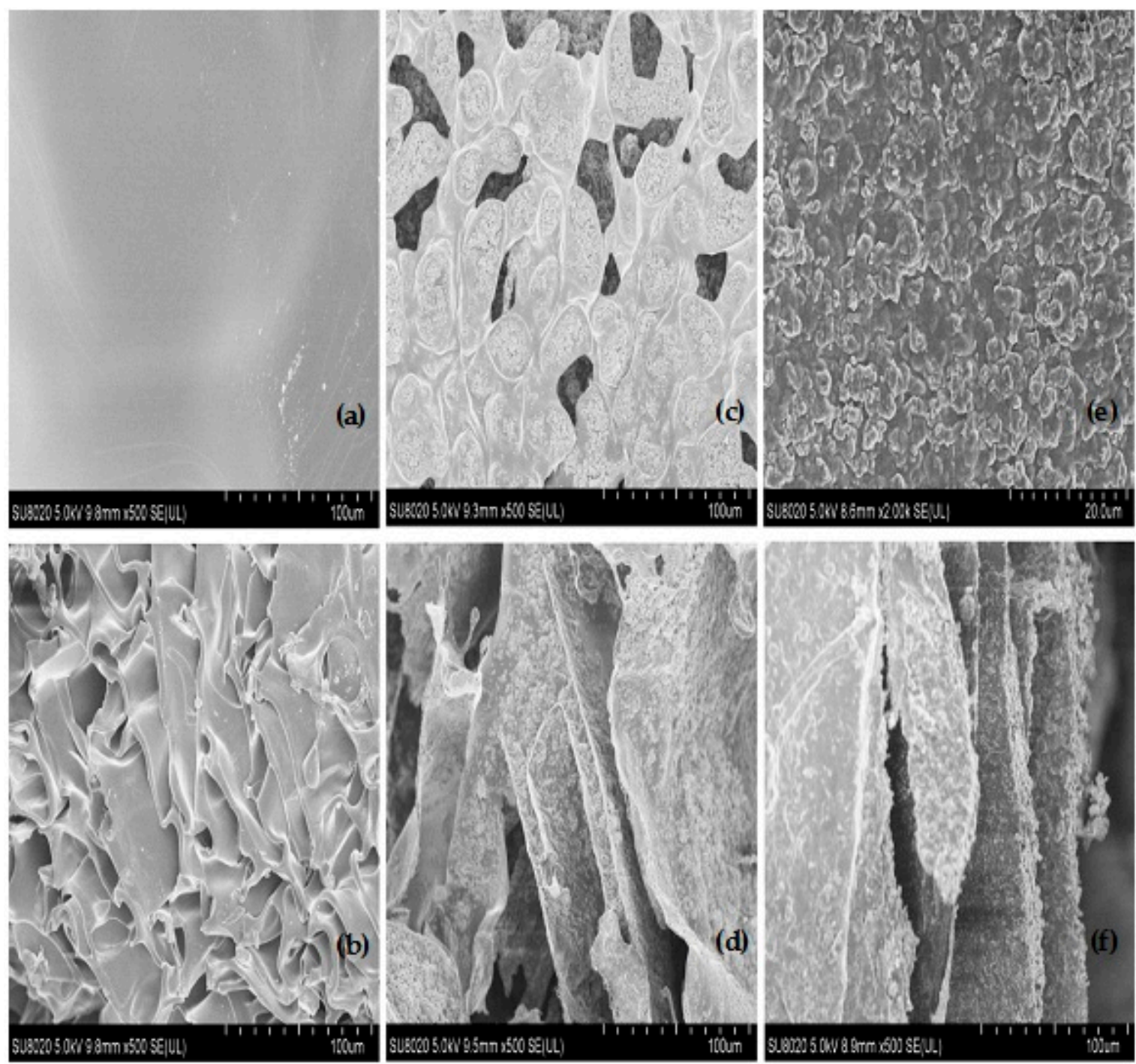

Figure 2. SEM images of surface and cross-section of chitosan $(\mathrm{CHN})$ film $(\mathbf{a}, \mathbf{b})$, silica/CHN film (c,d), and titanium/CHN film $(\mathbf{e}, \mathbf{f})$.

\section{2. $\mathrm{CO}_{2}$ Respiration Rate}

The high respiration rate is associated with low postharvest quality. Xu et al. [23] defined respiration as the oxidation of energy-rich organic molecules oxidation to simple molecules with the addition of producing energy. As presented in Figure 3a, the respiratory rate consistency increased initially and then declined during the end of the storage period in mushrooms, which meant that mushrooms were typical indicators for respiratory saltation [24]. Interestingly, in the M/Control samples, $\mathrm{CHN}$ and Titanium/CHN Films reached peak respiratory rate on 6th day while Silica/CHN Film reached the peak on 9th day. This can explain the fact that Silica/CHN Film strongly delayed the mushroom respiratory spike onset and blocked carbon dioxide passage from inside to the outside. 


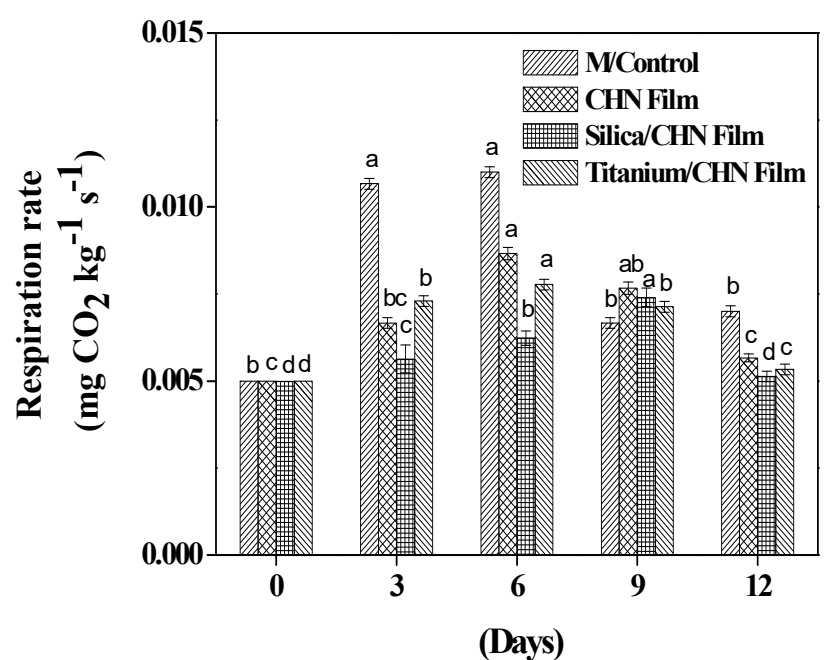

(a)

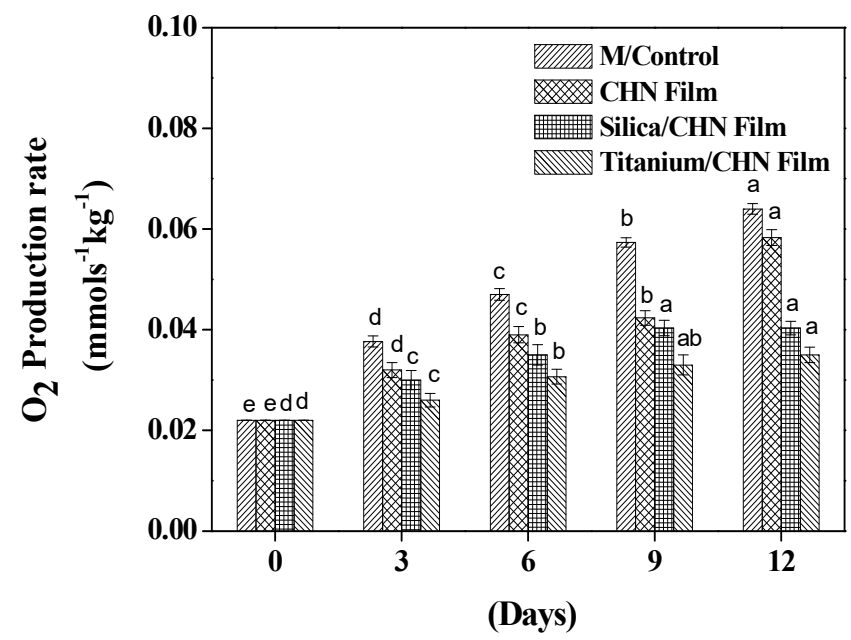

(b)

Figure 3. Effects of nanofilms on $\mathrm{CO}_{2}$ respiration $(\mathbf{a})$ and $\mathrm{O}_{2}(\mathbf{b})$ production rates; $\mathrm{a}, \mathrm{b}, \mathrm{c}, \mathrm{d}$,e mean significant differences between treatments at $p \leq 0.05$.

\section{3. $\mathrm{O}_{2}$ Production Rate}

$\mathrm{O}_{2}$ production is common mitochondrial respiration which can be able to destroy the cytoplasmic membrane inhibit lipid peroxidation, and lead to the senescence of mushrooms [20]. The effect of various coating films on $\mathrm{O}_{2}$ production rate during the whole storage period is presented in Figure $3 \mathrm{~b}$. Among all the mushroom samples, mushrooms coated with titanium/CHN film $\left(0.035 \mathrm{mmol} \mathrm{s}^{-1} \mathrm{~kg}^{-1}\right)$ established the lowest $\mathrm{O}_{2}$ production rate $(p<0.05)$ followed by silica/CHN film $\left(0.040 \mathrm{mmol} \mathrm{s}^{-1} \mathrm{~kg}^{-1}\right)$. Zhang et al. [25] reported decreases in $\mathrm{O}_{2}$ production rate on mushrooms by using other conditions such as mild heat.

\subsection{Total Polyphenols}

The changes in polyphenols contents of coated button mushrooms and stored at $4{ }^{\circ} \mathrm{C}$ during the whole storage period are shown in Figure 4a. In the current research work, mushroom bodies treated with silica/CHN and titanium/CHN films established a great increase in their polyphenols contents during the first 6 days of the storage period, respectively. At the end of the experiments time, the polyphenols contents of mushrooms coated with Silica/CHN Film was $\left(0.39 \mathrm{~g} \mathrm{~kg}^{-1}\right)$, compared with $\mathrm{M} /$ Control $\left(0.35 \mathrm{~g} \mathrm{~kg}^{-1}\right)$. Camargo and Dunoyer [26] reported that cold conditions can help in increasing the polyphenols contents by changing the phenolic metabolism. On the other hand, mushrooms coated with $\mathrm{CHN}$ film alone observed a slight increase compared with the other nano-coating films.

\subsection{DPPH Scavenging Activity}

Variation in free radical scavenging activity of coated mushrooms during storage is presented in Figure $4 \mathrm{~b}$. It is noticed that the initial DPPH scavenging activity value of immediately following harvest mushrooms was $52.14 \%$. DPPH scavenging activity of coated mushrooms with silica/CHN film (78.14\%) highly increased during storage compared with the other films. This could be associated with the fact that in cold conditions nanosilica, in combination with the chitosan coating, the polyphenol contents and DPPH scavenging activity, could reach saturation level in Agaricus bisporus bodies. Titanium/CHN films reduced lower DPPH scavenging activity values to reach (74.70\%). Thakur et al. [27] reported that the barrier improved by the coating process helped to reduce antioxidant compound loss during storage and improve the postharvest quality. Though, the DPPH scavenging activity of $\mathrm{M} /$ Control mushrooms raised on the 3rd day $(53.73 \%)$ and decreased significantly $(37.52 \%)$ on 12 th day of the storage period. 


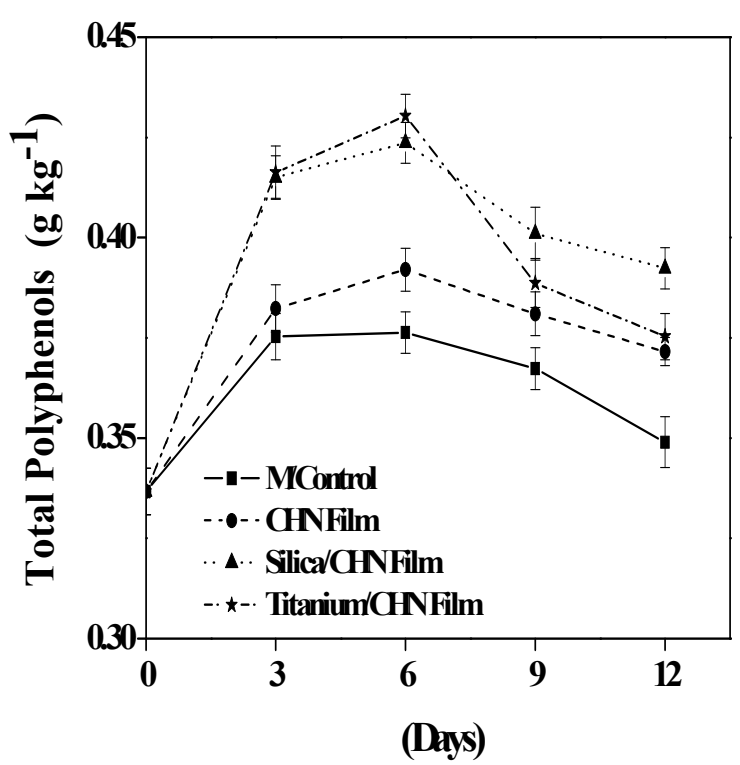

(a)

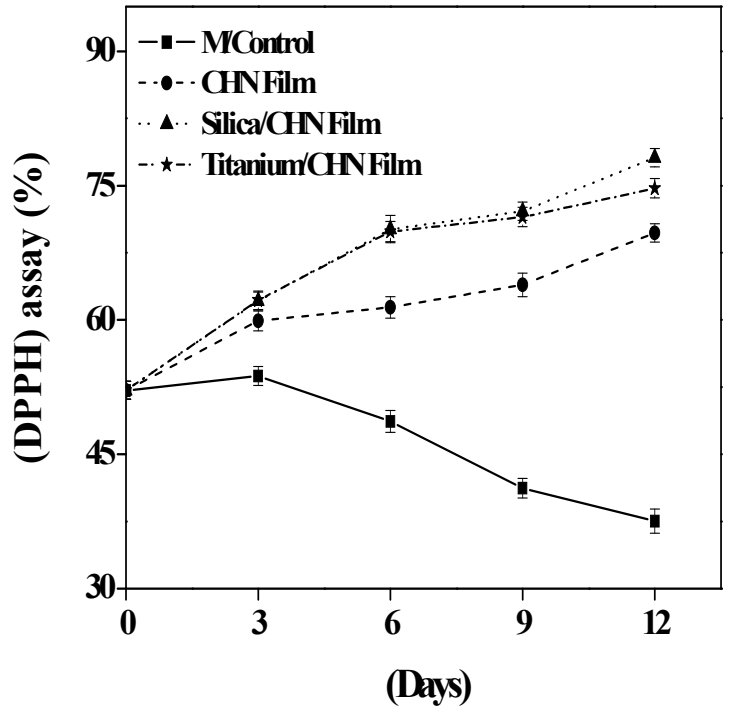

(b)

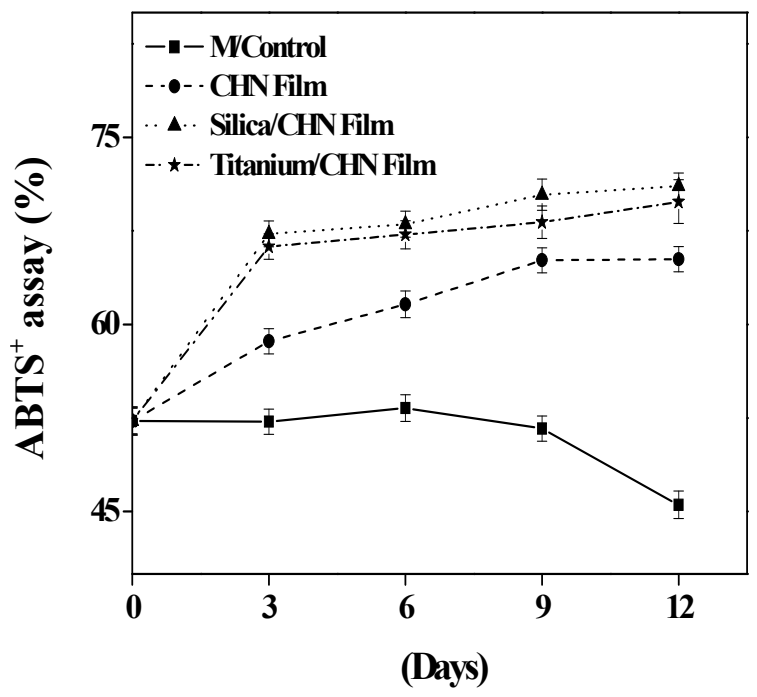

(c)

Figure 4. Effects of nanofilms on polyphenol contents (a) and antioxidant activities DPPH (b) and $\mathrm{ABTS}^{+}(\mathbf{c})$ radical scavenging activities. Data are mean \pm standard deviation (SD), $n=3$.

\subsection{ABTS $^{+}$Radical Scavenging}

Figure $4 \mathrm{c}$ presents the $\mathrm{ABTS}^{+}$radical scavenging activity of mushrooms subjected coating films and the storage time. The initial $\mathrm{ABTS}^{+}$radical scavenging activity of immediately following harvest mushrooms was $52.26 \%$. As a result of the coating film process, an increase in the ABTS+ radical scavenging activity was detected in all mushroom samples, ranging from $45.55 \%$ to $71.09 \%$. The highest, increase in the ABTS+ radical scavenging activity after the whole storage was detected by using silica/CHN film on mushroom samples followed by titanium/CHN and CHN films. The greater impact of the enhancement of the antioxidant activity was the presence of nano-films coating which declined the damage to tissues and native oxidoreductive enzymes [28].

\subsection{Effect of Coating on Oxidative Enzyme Activities}

As mentioned before, the most important concern with observe to the mushroom quality deterioration is associated with enzymes, such as POD, SOD, CAT, and APX [29,30]. Evaluating the effect of coating on POD activity is essential as it can cause the discoloration 
of mushrooms (Figure 5a). POD activity values firstly increased, then decreased, and reached the highest peak after 12 days of the storage period. POD activity values were inbetween (0.005-0.008 $\mathrm{U} \mathrm{kg}^{-1}$ ) of all mushroom samples. Karimirad et al., and Sami [31,32] reported that POD activity increase can be due to the oxidation of the polyphenols that lead to discoloration and nutrient losses. The current research reports that titanium/CHN film has the lowest POD activity on coated mushroom samples and suggests using it for the inhibiting POD activity. SOD is one of the major antioxidant enzymes in edible fungus which plays an important role in antioxidant defense by protecting the integrity of the membrane [15]. Time courses of SOD activity are presented in Figure 5b. SOD activity of button mushrooms in the absence of nano-films decreased slowly for M/Control and CHN Film, while in the presence of nano-films, it effectively preserved the oxidation activity. Moreover, the SOD activity value in the mushroom samples coated with titanium/CHN film reached the maximum $\left(6.76 \mathrm{U} \mathrm{kg}^{-1}\right)$ on the 3rd day of storage which was $\left(6.47 \mathrm{U} \mathrm{kg}^{-1}\right)$ higher than the peak value of the M/Control mushrooms. Mushroom samples coated with silica/CHN film reported the highest SOD activity $\left(6.52 \mathrm{U} \mathrm{kg}^{-1}\right)$ by the end of the storage period. It seems that nano-films were efficient in retaining oxidation enzyme levels which can be due to their ability for preserving phenolic compounds in treated mushrooms [33]. CAT activity increased in mushroom samples during storage time, Figure $5 \mathrm{c}$. The CAT activity first increased on the 6th day and then exhibited a minor drop over the next 6 days in both M/Control and CHN Film during the storage. Silica/CHN film $\left(0.47 \mathrm{U} \mathrm{kg}^{-1}\right)$ established the lowest value $(p \leq 0.05)$ followed by titanium/CHN film $\left(0.45 \mathrm{U} \mathrm{kg}^{-1}\right)$. Eissa, [29] reported a similar CAT activity value by using CHN film on shelf-life and quality measurements of button mushrooms. APX activity of M/Control mushrooms reported a slight increase on the 3rd day of the storage period $\left(6.01 \mathrm{U} \mathrm{kg}^{-1}\right)$ and then decreased linearly to reach $\left(4.14 \mathrm{U} \mathrm{kg}^{-1}\right)$ on the 12 th day, Figure $5 \mathrm{~d}$. That decrease in APX activity was detected also in other mushroom samples, while Silica/CHN film recorded the highest APX activity $\left(12.44 \mathrm{U} \mathrm{kg}^{-1}\right)$. It seems that the current research paper results were in agreement with the APX activity value of loquat fruit during the cold condition, especially by using chitosan/nano-silica film for retaining oxidation [34]. The mentioned results reported that silica/CHN film induced the highest (CAT and APX) activities, while titanium/CHN film recorded the highest (POD and SOD) activities of antioxidant enzymes during cold-storage.

\subsection{Effect of Coating on ROS Production}

Quality rapid reduction and marketing are influenced by ROS processes such as $\mathrm{H}_{2} \mathrm{O}_{2}$ and $-\mathrm{OH}$ [34]. As presented in Figure 6a, various coating films markedly inhibited the accumulation of $\mathrm{H}_{2} \mathrm{O}_{2}$ contents which increased until the 3rd day of storage. At the end of the storage period, higher $\mathrm{H}_{2} \mathrm{O}_{2}$ contents were detected in $\mathrm{M} / \mathrm{Control}$ samples $\left(41.23 \mu \mathrm{mol} \mathrm{g}^{-1}\right)$ than those in other coated mushrooms. CHN Film recorded somewhat a little high $\mathrm{H}_{2} \mathrm{O}_{2}$ content followed by silica/CHN film. Besides, mushroom samples coated by titanium/CHN film preserved relatively lower contents than those coated by silica/CHN film $(p \leq 0.05)$. $-\mathrm{OH}$ levels play an essential role during the oxidation process as browning increase can lead to $\mathrm{H}_{2} \mathrm{O}_{2}$ and $-\mathrm{OH}$ increase [35]. In the current research work, titanium/CHN film effectively reduced -OH level $\left(0.16 \mu \mathrm{mol} \mathrm{g}^{-1}\right)$ on mushrooms during storage (Figure $6 \mathrm{~b}$ ). In a word, nano-materials used in coating films such as titanium or even silica with the combination of $\mathrm{CHN}$ can directly reduce the cell degradation, oxidation processes, and enhance the harvested horticultural crops [9]. 


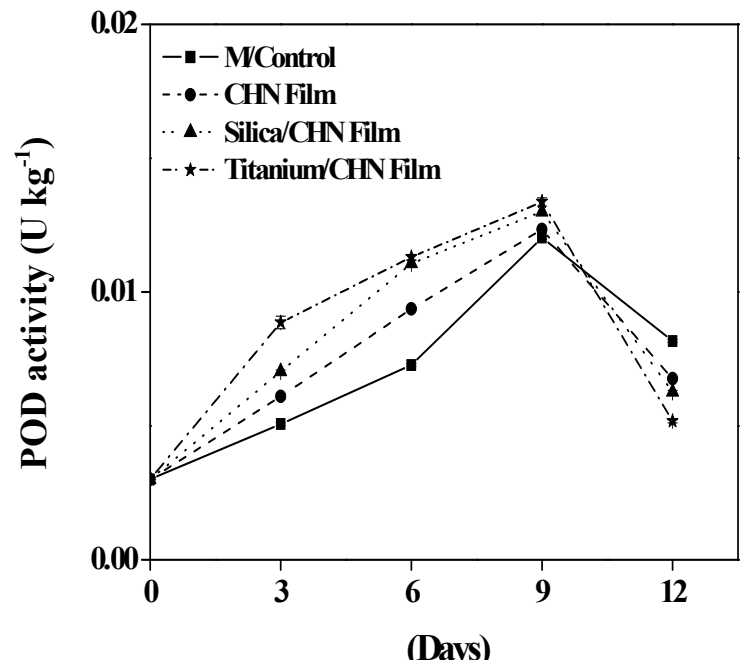

(a)

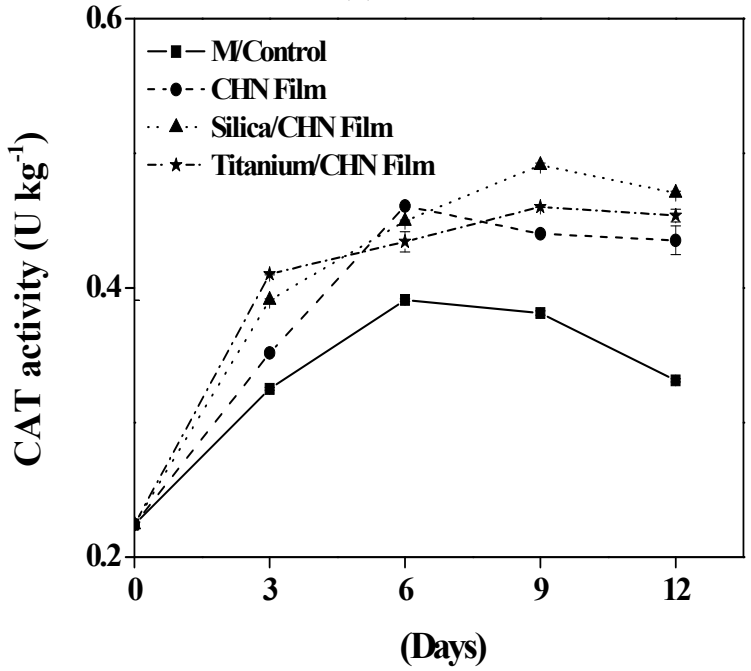

(c)

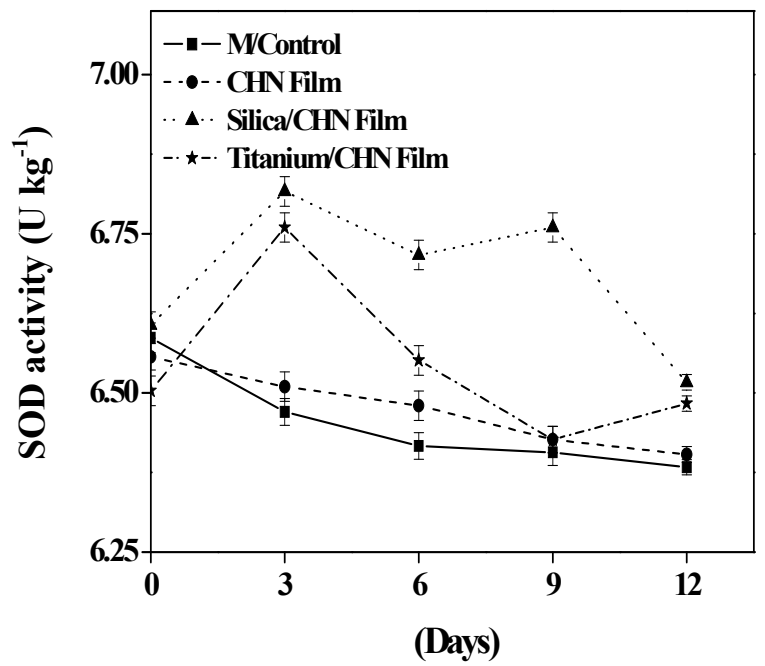

(b)

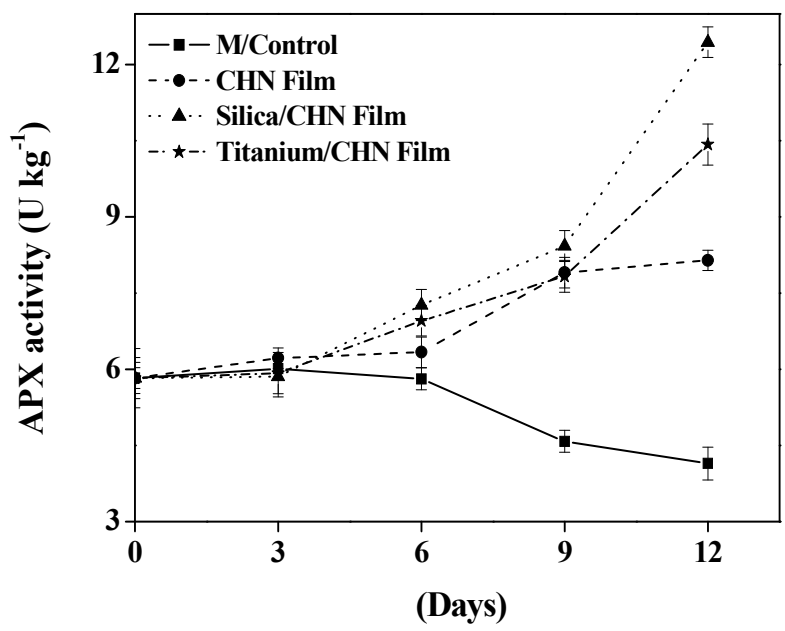

(d)

Figure 5. Effects of nanofilms on oxidative enzyme activities; Peroxidase (POD) (a), Superoxide dismutase (SOD) (b), Catalase (CAT) (c), and Ascorbate peroxidase (APX) (d). Data are mean $\pm \mathrm{SD}, n=3$.

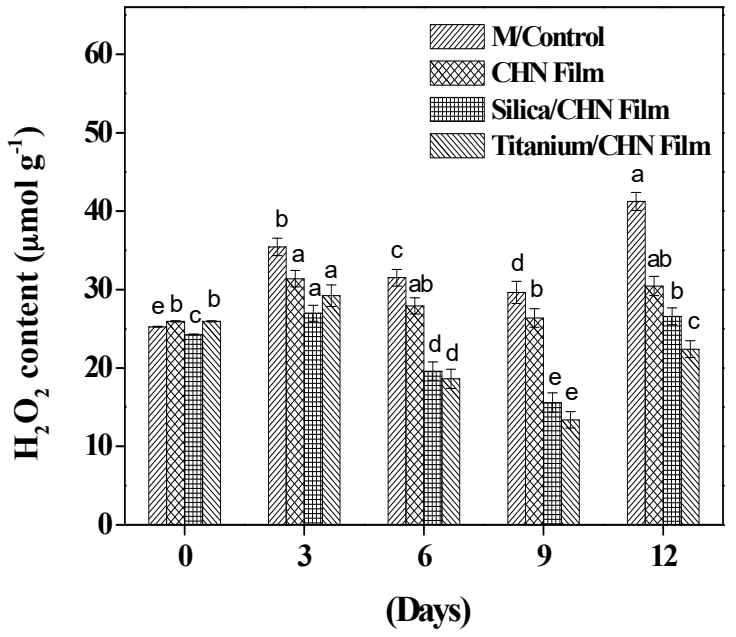

(a)

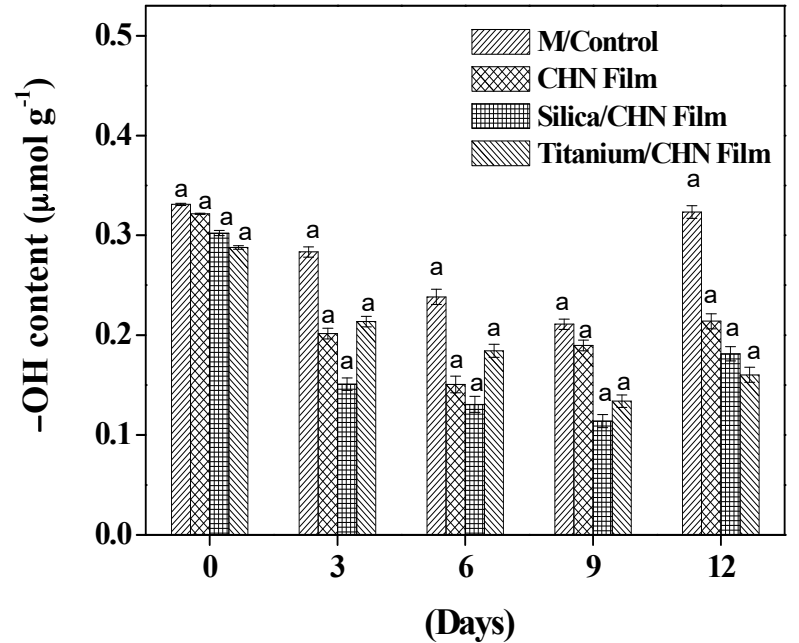

(b)

Figure 6. Effects of nanofilms on reactive oxygen species (ROS) production; $\mathrm{H}_{2} \mathrm{O}_{2}$ contents (a) and $-\mathrm{OH}$ levels (b); a,b,c,d,e mean significant differences between treatments at $p \leq 0.05$. 


\subsection{TBARS in Mushrooms}

Four mushroom samples were selected for evaluating TBARS and the results are presented in (Figure 7). The inertial value of titanium/CHN film has lower TBARS $\left(0.29 \mu \mathrm{mol} \mathrm{g}^{-1}\right)$ than silica/CHN film $\left(0.30 \mu \mathrm{mol} \mathrm{g}^{-1}\right)$, and CHN film $\left(0.32 \mu \mathrm{mol} \mathrm{g}^{-1}\right)$, while $\mathrm{M} / \mathrm{Control} \mathrm{recorded}\left(0.33 \mu \mathrm{mol} \mathrm{g}{ }^{-1}\right)$, respectively. The difference can be due to the effect of coating films applied. Amin et al. [8] recently revealed that Aloe vera gel coating treatment can reduce the browning of white button mushrooms and the TBARS values. By the end of the storage period, the results reported that both titanium/CHN and silica/CHN films inhibited TBARS accumulation and preserved the membrane integrity. wile, M/Control, and CHN film reported higher TBARS values $\left(0.32-0.21 \mu \mathrm{mol} \mathrm{g}^{-1}\right)$, respectively. The difference in the TBARS values can be due to the polarity and dissolution power of the solute and solvent in the coating materials [36].

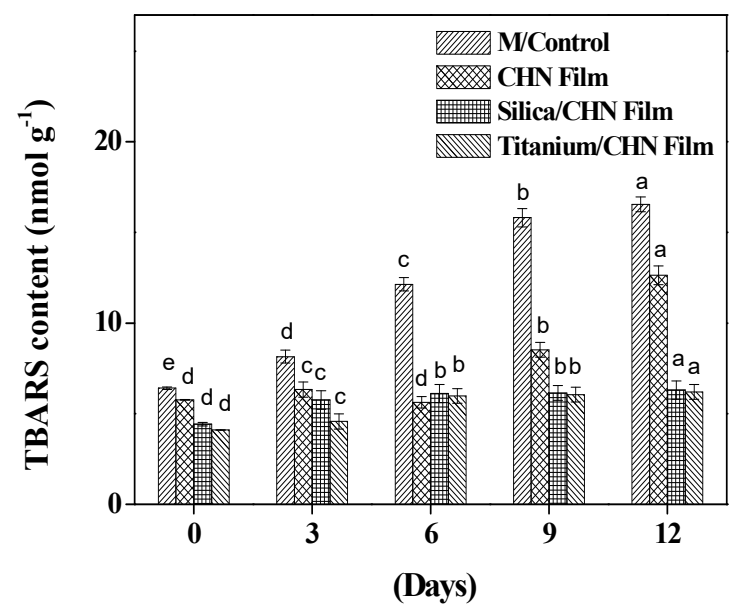

Figure 7. Effects of nanofilms on Thiobarbituric acid-reactive substances (TBARS) in mushrooms; $\mathrm{a}, \mathrm{b}, \mathrm{c}, \mathrm{d}, \mathrm{e}$ mean significant differences between treatments at $p \leq 0.05$.

\section{Conclusions}

The current research work proposed that there is a quality development of white button mushrooms by the combined effect of chitosan and nano-material coatings. Titanium/CHN film depicted higher peroxidase, superoxide dismutase, and caused very low $\mathrm{O}_{2}$, reactive oxygen species, and thiobarbituric acid-reactive substances productions during the whole storage period. Silica/CHN film was the most effective for the polyphenol component and antioxidant activities. Oxidation enzyme activities such as catalase and ascorbate peroxidase were the highest on treated button mushrooms by Silica/CHN Film. Besides, silica/CHN film enhanced the respiratory rate. This combination of nanomaterials and chitosan could have an efficient approach for the further research application on button mushroom preservation against the senescence and to retain their quality during commercial storage.

Author Contributions: Methodology, R.S. and M.A. (Manal Almatrafi); software, M.H.; writingreview and editing, M.H., N.B., R.S., A.E and A.A. visualization, M.H. and R.S.; funding acquisition, R.S., M.A. (Mona Alharbi), and N.B. All authors have read and agreed to the published version of the manuscript.

Funding: This research received no external funding.

Data Availability Statement: Available upon request from the corresponding author.

Acknowledgments: Taif University Researchers Supporting Project No. (TURSP-2020/140), Taif University, Taif, Saudi Arabia. This research was funded by the Deanship of Scientific Research at Princess Nourah bint Abdulrahman University through the Fast-track Research Funding Program.

Conflicts of Interest: The authors declared no conflicts of interest. 


\section{References}

1. Sami, R.; Khojah, E.; Elhakem, A.; Benajiba, N.; Chavali, M.; Vivek, K.; Iqbal, A.; Helal, M. Investigating the nano-films effect on physical, mechanical properties, chemical changes, and microbial load contamination of white button mushrooms during storage. Coatings 2021, 11, 44.

2. Sami, R.; Elhakem, A.; Alharbi, M.; Benajiba, N.; Almatrafi, M.; Jing, J.; Helal, M. Effect of Titanium Dioxide Nanocomposite Material and Antimicrobial Agents on Mushrooms Shelf-Life Preservation. Processes 2020, 8, 1632. [CrossRef]

3. Singh, N.; Vaidya, D.; Mishra, V.; Thakur, K. Shelf life and storage quality of white button mushrooms (Agaricus bisporus) as affected by packaging material. Int. J. Adv. Res 2016, 4, 1790-1799. [CrossRef]

4. Sedaghat, N.; Vahedi, N. Evaluation of several methods for preservation and packaging of the button white mushroom to increase its shelf life. Iran. Food Sci. Technol. 2015, 11, 22-30.

5. Gholami, R.; Ahmadi, E.; Farris, S. Shelf life extension of white mushrooms (Agaricus bisporus) by low temperatures conditioning modified atmosphere, and nanocomposite packaging material. Food Packag. Shelf Life 2017, 14, 88-95. [CrossRef]

6. Qiao, G.; Xiao, Z.; Ding, W.; Sami, R. Effect of Chitosan/Nano-Titanium Dioxide/Thymol and Tween Films on Ready-to-Eat Cantaloupe Fruit Quality. Coatings 2019, 9, 828. [CrossRef]

7. Srivastava, P.; Prakash, P.; Bunkar, D. Enhancement in physiological and sensory attributes of button mushroom (Agaricus bisporus) as influenced by chemical and modified atmospheric packaging (MAP) treatments at low temperature storage. Int. J. Chem. Stud 2020, 8, 2059-2064. [CrossRef]

8. Mirshekari, A.; Madani, B.; Golding, J.B. Aloe vera gel treatment delays postharvest browning of white button mushroom (Agaricus bisporus). J. Food Meas. Charact. 2019, 13, 1250-1256. [CrossRef]

9. Sami, R.; Jia, F.; Li, Y.; Nie, X.; Xu, J.; Han, R.; Yu, H.; Amanullah, S.; Almatrafi, M.M.; Helal, M. Application of nano-titanum dioxide coating on fresh Highbush blueberries shelf life stored under ambient temperature. LWT 2020, 110422.

10. Maneerat, C.; Hayata, Y. Antifungal activity of $\mathrm{TiO}_{2}$ photocatalysisagainst Penicilliumexpansum in vitro and in fruit tests. Int. J. Food Microbiol. 2006, 107, 99-103. [CrossRef] [PubMed]

11. Sami, R.; Khojah, E.; Elhakem, A.; Benajiba, N.; Helal, M. Chitosan, Nisin, Silicon Dioxide nanoparticles coating films effects on blueberry (Vaccinium myrtillus) quality. Coatings 2020, 10, 962.

12. Li, Y.; Sami, R.; Jia, F.; Nie, X.; Xu, J.; Elhakem, A.; Almatrafi, M.; Benajiba, N.; Helal, M. Shelf-Life, Quality, Safety Evaluations of Blueberry Fruits Coated with Chitosan Nano-Material Films. Sci. Rep. 2021, 11, 55. [CrossRef] [PubMed]

13. Sakinah, M.; Misran, A.; Mahmud, T.M.; Abdullah, S.; Azhar, M. Evaluation of storage temperature, packaging system and storage duration on postharvest quality of straw mushroom (Volvariella volvacea). Food Res. 2020, 4, 679-689.

14. Hu, Y.-H.; Chen, C.-M.; Xu, L.; Cui, Y.; Yu, X.-Y.; Gao, H.-J.; Wang, Q.; Liu, K.; Shi, Y.; Chen, Q.-X. Postharvest application of 4-methoxy cinnamic acid for extending the shelf life of mushroom (Agaricus bisporus). Postharvest Biol. Technol. 2015, 104, 33-41. [CrossRef]

15. Peng, Y.; Li, T.; Jiang, H.; Gu, Y.; Chen, Q.; Yang, C.; Liang, Q.W.; Liu, S.-Q.; Zhang, X. Postharvest biochemical characteristics and ultrastructure of Coprinus comatus. PeerJ 2020, 8, e8508. [CrossRef] [PubMed]

16. Qiao, G.; Wenxin, D.; Zhigang, X.; Sami, R.; Khojah, E.; Amanullah, S. Antioxidant and anti-inflammatory capacities of pepper tissues. Ital. J. Food Sci. 2020, 32. [CrossRef]

17. Abeer, H.E.; Almatrafi, M.M.; Benajiba, N.; Koko, M.Y.; Sami, R. Comparative analysis of bioactive compounds, antioxidant and anti-inflammatory activities of apple varieties. Asian J. Plant Sci. 2021, 20, 61-66.

18. Sami, R.; Li, C.-J.; Zhao, Y.; Li, Y.; Sun, C.-H. Cabbage (Brassica oleracea L. var. capitata) phytochemicals with antioxidant and anti-inflammatory potential. Asian Pac. J. Cancer Prev. 2013, 14, 6657-6662.

19. Elhakem, A.H.; Benajiba, N.; Khojah, E.; Koko, M.Y.; Sami, R. DPPH, FRAP and TAEC Assays with postharvest cabbage (Brassica Oleracca) parameters during the packaging process. Pak. J. Agric. Sci. 2020, 24, 182-187.

20. Liu, J.; Liu, S.; Zhang, X.; Kan, J.; Jin, C. Effect of gallic acid grafted chitosan film packaging on the postharvest quality of white button mushroom (Agaricus bisporus). Postharvest Biol. Technol. 2019, 147, 39-47. [CrossRef]

21. Dokhanieh, A.Y.; Aghdam, M.S. Postharvest browning alleviation of Agaricus bisporus using salicylic acid treatment. Sci. Hortic. 2016, 207, 146-151. [CrossRef]

22. Zhang, L.; Liu, Z.; Wang, X.; Dong, S.; Sun, Y.; Zhao, Z. The properties of chitosan/zein blend film and effect of film on quality of mushroom (Agaricus bisporus). Postharvest Biol. Technol. 2019, 155, 47-56. [CrossRef]

23. Xu, Y.; Tian, Y.; Ma, R.; Liu, Q.; Zhang, J. Effect of plasma activated water on the postharvest quality of button mushrooms, Agaricus bisporus. Food Chem. 2016, 197, 436-444. [CrossRef] [PubMed]

24. Qin, Y.; Liu, D.; Wu, Y.; Yuan, M.; Li, L.; Yang, J. Effect of PLA/PCL/cinnamaldehyde antimicrobial packaging on physicochemical and microbial quality of button mushroom (Agaricus bisporus). Postharvest Biol. Technol. 2015, 99, 73-79. [CrossRef]

25. Zhang, L.; Li, S.; Wang, A.; Li, J.; Zong, W. Mild heat treatment inhibits the browning of fresh-cut Agaricus bisporus during cold storage. LWT Food Sci. Technol. 2017, 82, 104-112. [CrossRef]

26. Camargo, J.M.; Dunoyer, A.T.; García-Zapateiro, L.A. The effect of storage temperature and time on total phenolics and enzymatic activity of sapodilla (Achras sapota L.). Rev. Fac. Nac. Agron. Medellín 2016, 69, 7955-7963. [CrossRef]

27. Thakur, R.R.; Shahi, N.C.; Mangaraj, S.; Lohani, U.C.; Chand, K. Effect of apple peel based edible coating material on physicochemical properties of button mushrooms under ambient condition. Int. J. Chem. Stud. 2020, 8, 2362-2370. [CrossRef] 
28. Walkowiak-Tomczak, D.; Idaszewska, N.; Bieńczak, K.; Kómoch, W. The effect of mechanical actions occurring during transport on physicochemical changes in Agaricus bisporus mushrooms. Sustainability 2020, 12, 4993. [CrossRef]

29. Eissa, H.A. Effect of chitosan coating on shelf-life and quality of fresh-cut mushroom. Pol. J. Food Nutr. Sci. 2008, 58, 95-105. [CrossRef]

30. Hosseini, A.; Moradinezhad, F. Effect of short-term high $\mathrm{CO}_{2}$ treatment on quality and shelf life of button mushroom (Agaricus bisporus) at refrigerated storage. J. Hortic. Postharvest Res. 2018, 1, 37-48.

31. Karimirad, R.; Behnamian, M.; Dezhsetan, S. Development and characterization of nano biopolymer containing cumin oil as a new approach to enhance antioxidant properties of button mushroom. Int. J. Biol. Macromol. 2018, 113, 662-668. [CrossRef] [PubMed]

32. Sami, R. Application of Nano-coating and Chitosan Combination Films on Cantaloupe Preservation. Pak. J. Biol. Sci. PJBS 2020, 23, 1037-1043.

33. Karimirad, R.; Behnamian, M.; Dezhsetan, S. Application of chitosan nanoparticles containing Cuminum cyminum oil as a delivery system for shelf life extension of Agaricus bisporus. LWT 2019, 106, 218-228. [CrossRef]

34. Song, H.; Yuan, W.; Jin, P.; Wang, W.; Wang, X.; Yang, L.; Zhang, Y. Effects of chitosan/nano-silica on postharvest quality and antioxidant capacity of loquat fruit during cold storage. Postharvest Biol. Technol. 2016, 119, 41-48. [CrossRef]

35. Wang, Z.; Chen, L.; Yang, H.; Wang, A. Effect of exogenous glycine betaine on qualities of button mushrooms (Agaricus bisporus) during postharvest storage. Eur. Food Res. Technol. 2015, 240, 41-48. [CrossRef]

36. Zeb, A.; Ullah, F. A simple spectrophotometric method for the determination of thiobarbituric acid reactive substances in fried fast foods. J. Anal. Methods Chem. 2016, 2016, 9412767. [CrossRef] 